\title{
Identification of the potential inhibitors of malolactic fermentation in wines
}

\author{
Renata Vieira da MOTA ${ }^{1 *}$, Cintia Lacerda RAMOS², Isabela PEREGRINO ${ }^{1}$, Neuza Mariko Aymoto HASSIMOTTO \\ Eduardo PURGATTO ${ }^{3}$, Claudia Rita de SOUZA ${ }^{1}$, Disney Ribeiro DIAS ${ }^{4}$, Murillo de Albuquerque REGINA ${ }^{1}$
}

\begin{abstract}
This exploratory work aims to identify the potential inhibitors of lactic bacterial growth and to propose enological practices to guarantee the occurrence of spontaneous malolactic fermentation (MLF) in wines from traditional and double-pruning management harvests in southeast Brazil. One white wine from a summer harvest and one red wine from a winter harvest that failed to complete MLF were utilized as comparative models to identify inhibitor compounds to lactic bacteria. Wine composition, alcoholic-fermentation temperature and bacterial strain contribute to the success or failure of MLF. Temperatures below $12{ }^{\circ} \mathrm{C}$ during alcoholic fermentation decrease lactic bacterial metabolism and may impair the bacteria's growth after yeast cells lysis. A must $\mathrm{pH}$ below 3.2 in a summer harvest impairs bacterial growth, and the association of low $\mathrm{pH}$ with a free- $\mathrm{SO}_{2}$ concentration above $10 \mathrm{mg} \mathrm{L}^{-1}$ may inhibit MLF. For grapes with a high sugar content, harvested in the winter cycle, enologists should keep the alcohol content below $15 \%$ and control the alcoholic-fermentation temperature.
\end{abstract}

Keywords: Vitis; winemaking; lactic bacteria; malic acid; composition.

Practical Application: Wineries in the southeast region of Brazil have a busy post-harvest period, since they must attend to the demand of summer and winter harvests. Early and rapid MLF results in more efficient utilization of the tanks and, furthermore, reduces the risk of microbiological spoilage and allows for early commercialization of the wines.

\section{Introduction}

Malolactic fermentation plays an important role in reducing acidity and improving both the microbiological stability and the aroma profile of wines. The conditions required for the induction and appropriate course of MLF include initial temperatures of $20{ }^{\circ} \mathrm{C}$ to $25^{\circ} \mathrm{C}$, a free- $\mathrm{SO}_{2}$ content below $10 \mathrm{mg} \mathrm{L}^{-1}$, a total $\mathrm{SO}_{2}$ concentration below $30 \mathrm{mg} \mathrm{L}^{-1}$, a $\mathrm{pH}$ level between the range of 3.2 and 3.4, and nutrients, which are obtained from the sediment of yeast cells (Lasik, 2013). Spontaneous MLF, however, cannot be guaranteed due to the harsh environmental conditions present in wine. Malolactic fermentation may fail or occur many months after alcoholic fermentation is complete, which impairs the production processes and may cause wine-depreciation associated with the occurrence of spoilage or the production of toxic compounds (Iorizzo et al., 2016).

Growth studies with different strains of lactic bacteria in culture media indicated that temperature, acetaldehyde- and pyruvic acid-bound $\mathrm{SO}_{2}$, low $\mathrm{pH}$, high amounts of tannins, pesticide residue, high levels of ethanol and medium-chain fatty acids may impair bacterial growth and activity (Wells \& Osborne, 2012; Lasik, 2013). The inoculation of resistant strains of lactic bacteria simultaneously with yeast or just after alcoholic fermentation has been proposed as an alternative to reduce the duration of MLF (Suriano et al., 2015; Lerena et al., 2016). However, using commercial strains to induce MLF is costly and not always successful; it depends on the geographical origin and adaptation to the winemaking conditions of each wine (Iorizzo et al., 2016).

Southeast Brazil emerged as a new fine-wine viticultural region due to the introduction of double-pruning management (Favero et al., 2011; Regina et al., 2011). Grapes from a winter harvest have higher levels of malic acid than those harvested in the summer (Mota et al., 2010), and MLF is an essential practice to guarantee the quality of the wine. Wineries in the southeast deal with two annual crops; therefore, rapid MLF is indispensable not only to guarantee the quality of the wine but also to optimize the utilization of tanks in the wineries.

As far as the authors know, there are no studies regarding the behavior of native strains of lactic bacteria from the vineyards of southeast Brazil. This initial exploratory work aims to identify the potential inhibitors of native lactic bacteria in traditional vinification (summer harvests) and winter wines (double-pruning management), and to suggest enological practices to ensure the occurrence of faster MLF.

${ }^{3}$ Departamento de Alimentos e Nutrição Experimental, Faculdade de Ciências Farmacêuticas, Universidade de São Paulo - USP, São Paulo, SP, Brazil

${ }^{4}$ Departamento de Ciência dos Alimentos, Universidade Federal de Lavras - UFLA, Lavras, MG, Brazil

*Corresponding author: renata@epamigcaldas.gov.br 


\section{Material and methods}

\subsection{Samples}

Grapes from the cultivars Syrah, Tempranillo, Cabernet sauvignon, Chardonnay and Bordô (Yves) from vineyards settled in Andradas, Baependi, Caldas, Divinolândia, Santo Antônio do Amparo, São Sebastião do Paraíso, Três Corações and Três Pontas in Minas Gerais State; Indaiatuba, Itobi, Louveira, São Bento do Sapucaí and Vargem in São Paulo; and Itaipava in Rio de Janeiro were harvested in winter of the 2012 season, summer and winter of the 2013 season and winter of 2014. Plants were trained in a vertical-shoot position with bilateral cordons, and pruned in two-node spurs for both traditional and double-pruning management, totaling 20 latent buds per plant on average. Double-pruning management was applied according to the methodology described by Favero et al. (2011). Vineyards were not irrigated, and phytosanitary treatments followed the instructions for grape production.

The harvest date was determined based on the following data: total soluble solids in the range of 22 to $25^{\circ}$ Brix for winter harvest and 16 to $18{ }^{\circ} \mathrm{Brix}$ for summer harvest, and total titratable acidity in the range of 5.6 to $7.5 \mathrm{~g} \mathrm{~L}^{-1}$ for winter harvest and 3.7 and $9.7 \mathrm{~g} \mathrm{~L}^{-1}$ for Bordô and Chardonnay grapes, respectively, in summer harvest and $\mathrm{pH} 3.4$ to 3.6 in winter harvest and 3.2 to 3.3 in summer harvest in a sample of 100 random berries that were collected in the vineyard. For grapes harvested in the winter season, the berries' phenolic maturation, which was determined through organoleptic evaluation of the berries, was also taken into account. The harvested grapes were delivered at the winery and stored at $4{ }^{\circ} \mathrm{C}$ for $24 \mathrm{~h}$.

No additional treatment was imposed on the samples. Red and white winemaking were performed according to the daily practices of the winery.

\subsection{Red winemaking}

Grape clusters were destemmed, crushed and transferred to $300 \mathrm{~L}$ steel fermentation tanks equipped with temperature control systems. Sulfite at $10 \mathrm{~g} \mathrm{hL}^{-1}$ was added to grape must and then the must was inoculated with $20 \mathrm{~g} \mathrm{hL}^{-1}$ of rehydrated active Saccharomyces cerevisiae yeast strain AWRI 796 (Maurivin) and $3 \mathrm{~g} \mathrm{hL}^{-1}$ of pectolytic enzyme. Pumping-over operations were performed twice a day during active fermentation. The vatting time was adjusted for each wine according to the winemaker's perception. The fermentation rate was monitored daily using temperature and density measures. Wines were runned off immediately after fermentation (density $990 \mathrm{mg} \mathrm{L}^{-1}$ ) and placed in recipients with a Muller valve to complete MLF. Paper chromatography was utilized to monitor MLF based on the depletion of malic acid (Amerine \& Ough, 1980). The length of time between running off and the complete degradation of malic acid determined the MLF period. At the end of the MLF process, wines were racked to remove lees, sulfite at $35 \mathrm{mg} \mathrm{L}^{-1}$ free $\mathrm{SO}_{2}$ was added and the wines were frozen at $-3{ }^{\circ} \mathrm{C}$ for 15 days to allow tartaric stabilization. Wines were bottled after two additional racking processes at 3-month periods and were kept in a dark cell.

\subsection{White winemaking (base wines)}

Juice was extracted at a temperature lower than $15^{\circ} \mathrm{C}$ by whole-cluster pneumatic pressing at $1 \mathrm{kbar}$. Grape must was immediately transferred to $300 \mathrm{~L}$ steel fermentation tanks equipped with temperature control systems, sulfited at $10 \mathrm{~g} \mathrm{hL}^{-1}$, and combined with $3 \mathrm{~g} \mathrm{hL}^{-1}$ of pectolytic enzyme and $1 \mathrm{~g} \mathrm{~L}^{-1}$ of bentonite. After 24 hours, the clarified must was racked and transferred to $100 \mathrm{~L}$ steel fermentation tanks with temperature control systems, and inoculated with $20 \mathrm{~g} \mathrm{hL}^{-1}$ of rehydrated active Saccharomyces cerevisiae yeast strain PDM (Maurivin). Fermentation was performed at a low temperature $\left(15^{\circ} \mathrm{C}\right)$ and monitored daily using temperature and density measures. Wines were racked immediately after fermentation (density $990 \mathrm{mg} \mathrm{L}^{-1}$ ) and placed in recipients with a Muller valve to complete spontaneous MLF at an ambient temperature. At the end of the MLF process, wines were racked to remove lees and frozen at $-3{ }^{\circ} \mathrm{C}$ for clarification. Wines were racked and bottled, and "tirage liqueur" and an active-yeast starter were added for the second fermentation.

\subsection{Sampling and bacterial enumeration}

Grape berries were immersed in $0.1 \%$ peptone water containing 20\% glycerol and must, and wines were combined with $20 \%(\mathrm{v} / \mathrm{v})$ of glycerol and kept at $-20{ }^{\circ} \mathrm{C}$.

Bacterial enumeration was carried out by spot plating $25 \mu \mathrm{L}$ droplets of culture samples, which were appropriately diluted with peptone water $(0.1 \%)$ to produce 5 to 50 colonies per spot, onto the surface of plates of de Man, Rogosa and Sharpe agar media (Amyl Media, Australia) that contained 10\% (v/v) preservative-free tomato juice (MRS-TJ) at a $\mathrm{pH}$ of 4.0 combined with cycloheximide $\left(100 \mathrm{mg} \mathrm{L}^{-1}\right)$. The agar plates were incubated at $37^{\circ} \mathrm{C}$ for 5 to 7 days without oxygen before the colonies were counted. Presumptive lactic bacteria were identified according to gram-positive and catalase-negative properties.

\subsection{DNA extraction and PCR assay}

The total DNA of the berry, must and wine samples was extracted with a PureLink Genomic-DNA mini kit (Invitrogen) according to the manufacturer's instructions, and DNA samples were tested in $1 \%$ agarose gel. Lactic-bacteria DNA was amplified with the following primers, according to Lopez et al. (2003): WLAB1 (5'-TCCGGATTTATTGGGCGTAAAGCGA-3'; nt 565 to 589) and WLAB2 (5'-TCGAATTAAACCACATGCTCCA-3'; nt 951 to 972) with tail GC (5'-CGCCCGCCGCGCCCCGCGCCCGGCCCGCCGCCCCCGCCCC3'). Reaction products were resolved by electrophoresis in $1 \%$ agarose gels, and they were visualized using ethidium-bromide staining. The purified PCR fragments were used for PCR-DGGE sequencing with the DCode Universal Mutation-Detection System (BioRad, Richmond, CA, EUA) according to Ramos et al. (2010). The denaturation gradient ranged from $30 \%$ to $60 \%$ (where $100 \%$ corresponds to urea $7 \mathrm{M}$ and formamide $40 \% \mathrm{v} / \mathrm{v}$ ). Electrophoresis was performed at $200 \mathrm{~V}$ for 4 hours at $60{ }^{\circ} \mathrm{C}$, and gels were stained with SYBR-Green I (molecular probes), using a ratio of $1: 10,000 \mathrm{v} / \mathrm{v}$, for $30 \mathrm{~min}$. 


\subsection{Wine composition}

Physicochemical analyses consisted of alcohol, total titratable acidity ( $\mathrm{g} \mathrm{L}^{-1}$ tartaric acid), volatile acidity ( $\mathrm{g} \mathrm{L}^{-1}$ acetic acid), $\mathrm{pH}$, sugars $\left(\mathrm{g} \mathrm{L}^{-1}\right.$ glucose), free and total $\mathrm{SO}_{2}\left(\mathrm{mg} \mathrm{L}^{-1}\right)$, dry extract, and ashes (Amerine \& Ough, 1980).

Total polyphenol indices $(280 \mathrm{~nm})$ were evaluated by spectrophotometry, and total flavanoid content by the Bate-Smith reaction (Ribéreau-Gayon et al., 2006). Total phenolics were measured using the Folin-Ciocalteau method (Amerine \& Ough, 1980).

Phenolic compounds were quantified by both HPLC-DAD-MS (Shimadzu, Prominence, Japan) and an ion-trap MS model Esquire HCT (BrukerDaltonics, Germany) with an electrospray (ESI) mode. Mobile phase consisted of acetonitrile and a $0.5 \%$ aqueous solution of formic acid at $1 \mathrm{~mL} \mathrm{~min}^{-1}$ for $45 \mathrm{~min}$ in a Prodigy $5 \mu \mathrm{m} \mathrm{ODS}_{3} 250 \times 4.60 \mathrm{~mm}$ column (Phenomenex Ltda, UK) at $25^{\circ} \mathrm{C}$. Eluting compounds were detected by UV absorbance at $270 \mathrm{~nm}$ and $370 \mathrm{~nm}$; thereafter the flux was reduced to $0.2 \mathrm{~mL} \mathrm{~min}^{-1}$ to pass through the ESI source. Positive-mode ESI ionization was applied for anthocyanins at 3,500 V, while a negative mode was applied for flavonols and phenolic acids at $3,000 \mathrm{~V}$, both in a full $100 \mathrm{~m} / \mathrm{z}$ to $1,000 \mathrm{~m} / \mathrm{z}$ scan. Peaks were identified and quantified using an external standard calibration of quercetin and chlorogenic acid (Sigma Aldrich, EUA), and the results were expressed as the $\mathrm{mg} \mathrm{g}^{-1}$ quercetin equivalent.

The presence of pesticide residues (cimoxanyl, phenamidone, dimetomorphe, metalaxyl, dithiocarbamate and cooper) as potential inhibitors of MLF was investigated in Chardonnay wines from Andradas and Caldas. AgroSafety, an external laboratory that is accredited by the Brazilian Department of Agriculture, performed the analyses.

Other potential inhibitors, such as acetaldehyde; decanoic and dodecanoic fatty acids; and pyruvic acid, were also investigated in Tempranillo (Vargem), Chardonnay (Caldas), Syrah (Itobi) and Chardonnay (Andradas) wines. The following external laboratories performed the analyses: Randon Laboratory (Caxias do Sul, Brazil), the Science and Food Quality Center at the Institute of Food Technology (ITAL, Campinas, Brazil), and the Food-Chemistry and Biochemistry Laboratory at the Faculty of Pharmacy, University of São Paulo (São Paulo, Brazil).

\section{Results and discussion}

As expected, spontaneous MLF was unpredictable. In the 20 wine samples that were investigated from different cultivars, vineyards and seasons, MLF lasted between 37 and 125 days and failed in two wines, namely Chardonnay (Caldas) and Tempranillo (Vargem). These two wines were used as models to identify the potential inhibitors of lactic bacteria.

There were no reports about direct influence of the temperature of alcoholic fermentation in MLF. Lasik (2013) notes that the appropriate conditions required for MLF induction include an initial temperature of between $20{ }^{\circ} \mathrm{C}$ and $25^{\circ} \mathrm{C}$, falling to between $18^{\circ} \mathrm{C}$ and $20^{\circ} \mathrm{C}$ during the MLF process. Temperatures between $15{ }^{\circ} \mathrm{C}$ and $20^{\circ} \mathrm{C}$ would stimulate MLF, while values above or below this range would reduce the population of active lactic bacteria.
Data presented in Figure 1 indicate that there is no clear correlation between temperature and the length of MLF.

Data from the same cultivar and viticultural region, however, show that a decrease in alcoholic-fermentation temperature increases the length of MLF (Figure 2).

Bokulich et al. (2013) observed that the microbial population correlates to specific climactic features, suggesting a link between a vineyard's environmental conditions and microbial patterns during wine fermentations. Therefore, the knowledge of native lactic bacteria from each viticultural region may contribute to the enhancement of MLF practices.

The indigenous lactic-bacteria population present in berries, must and wine were evaluated in the 2013 season in an MRS agar medium containing tomato juice. Lactic acid bacterial growth over $5 \times 10^{1} \mathrm{FCU} \mathrm{mL}^{-1}$ was observed in $63 \%$ of the berries, in $50 \%$ of the must samples and $14 \%$ of the wines after the

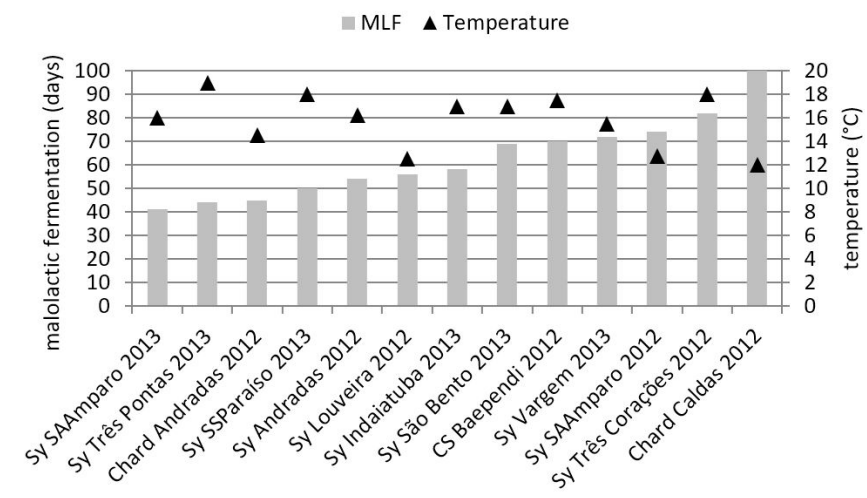

Figure 1. Lengths of MLF (days from running off to the complete degradation of malic acid) and the alcoholic-fermentation temperatures of wines from different regions in southeast Brazil that were harvested in summer or winter (double-pruning management). Sy = Syrah; Chard $=$ Chardonnay and CS $=$ Cabernet sauvignon.

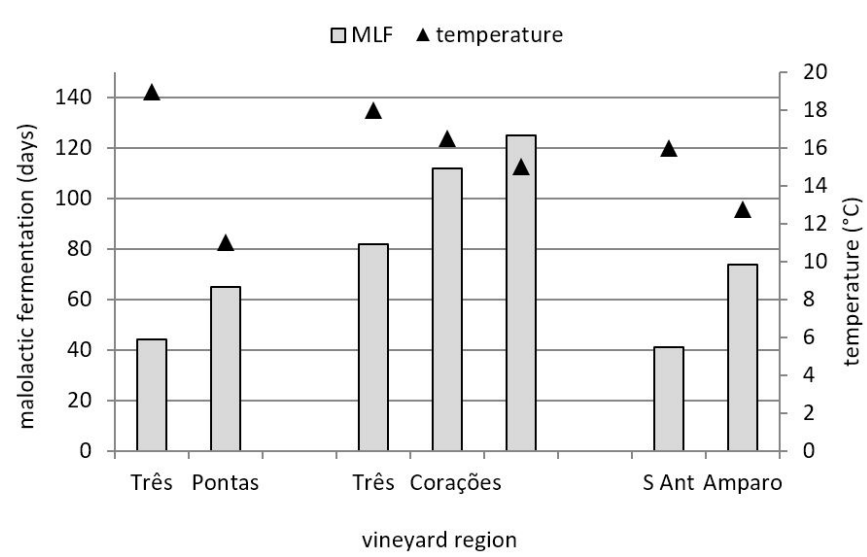

Figure 2. Lengths of MLF (days from running off to the complete degradation of malic acid) and alcoholic-fermentation temperatures of Syrah wines from Três Pontas, Três Corações and Santo Antônio do Amparo in the south of Minas Gerais State, Brazil, that were harvested in winter (double-pruning management). 
run-off operation. No growth was observed in samples during MLF or in bottled wine; however, all the samples, apart from the Tempranillo (Vargem) and Chardonnay (Caldas) wines, displayed complete degradation of malic acid. Although not detected by spot plating, PCR-DGGE confirmed the presence of lactic bacteria in all samples with different bands according to the viticultural region (Figure 3).

Chardonnay (CH-CAL) and Bordô (FF-CAL) from vineyards in Caldas had similar bands, while Cabernet franc (CAB-FC), which is also from Caldas, had a different profile. Chardonnay and Bordô grapes were harvested in the summer season on December $20^{\text {th }}, 2012$ and January $8^{\text {th }}, 2013$, respectively, in high-humidity conditions (200 mm). Cabernet franc, although harvested in the summer season (February 20 $\left.0^{\text {th }}, 2014\right)$, ripened in drier conditions (only $50 \mathrm{~mm}$ ). Reguant et al. (2005) and Ruiz et al. (2010) mentioned the variable strains of lactic bacteria in different seasons. These authors observed high genotype variability in consecutive seasons in the same vineyard with the selection and adaptation of native strains.

The conditions found in wine, such as low $\mathrm{pH}$ values, high alcohol content and high $\mathrm{SO}_{2}$ concentrations, compromise bacterial survival and growth (Pan et al., 2011; Iorizzo et al., 2016). Growth studies that were performed with isolated strains of lactic bacteria in media containing inhibitor compounds demonstrated that Oenococcus can grow at a $\mathrm{pH}<3.5$, while Pediococcus and Lactobacillus prefer a $\mathrm{pH}>3.5$. An ethanol concentration above $13 \%$ decreases the lactic-bacteria population with higher tolerances to Oenococcus (Edwards \& Beelman, 1989). These findings are well known; however, most of the studies were performed in controlled conditions with pure bacterial strains and synthetic media.
To identify probable inhibitors, the composition of different wines from summer and winter harvesting was compared with the length of MLF (Table 1).

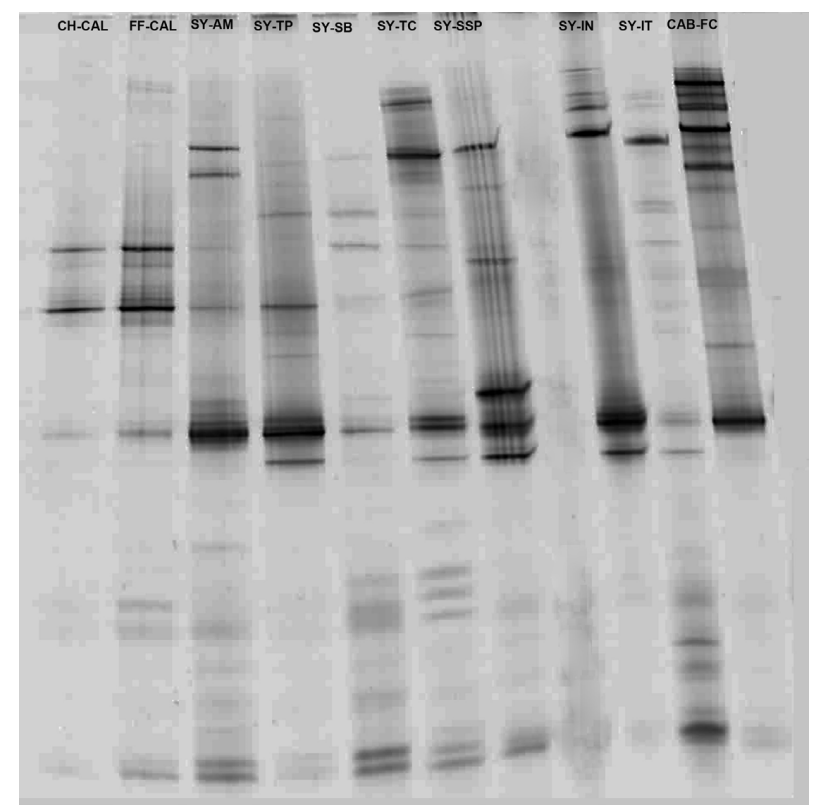

Figure 3. PCR-DGGE fragments of lactic bacteria found in berries of different cultivars and vineyards. $\mathrm{CH}-\mathrm{CAL}=$ Chardonnay (Caldas); FF-CAL = Bordô (Caldas); SY-AM = Syrah (Santo Antônio do Amparo); SY-TP = Syrah (Três Pontas); SY-SB = Syrah (São Bento); SY-TC = Syrah (Três Corações); SY-SSP = Syrah (São Sebastião do Paraiso); SY-IN = Syrah (Indaiatuba); SY-IT = Syrah (Itaipava) and $\mathrm{CAB}-\mathrm{FC}=$ Cabernet franc (Caldas).

Table 1. Lengths of MLF (days from running off to the complete degradation of malic acid) and chemical compositions of wines from different cultivars and viticultural regions in southeast Brazil that were harvested in the winter (double-pruning management) and summer (traditional) seasons.

\begin{tabular}{|c|c|c|c|c|c|c|c|}
\hline Vineyard & Cultivar & Season ${ }^{\star}$ & $\begin{array}{l}\mathrm{MLF}^{\dagger} \\
\text { (days) }\end{array}$ & $\begin{array}{c}\text { Free } \mathrm{SO}_{2} \\
\left(\mathrm{mg} \mathrm{L}^{-1}\right)\end{array}$ & $\mathrm{pH}$ & $\begin{array}{c}\text { Sugars } \\
\left(\mathrm{g} \mathrm{L}^{-1}\right)\end{array}$ & $\begin{array}{c}\text { Alcohol } \\
(\%)\end{array}$ \\
\hline Caldas & Bordô & $2012 S$ & 37 & 34.4 & 3.28 & 2.66 & 12.32 \\
\hline Andradas & Chardonnay & $2012 S$ & 45 & 12.8 & 3.19 & 0.94 & 11.65 \\
\hline Divinolândia & Chardonnay & $2012 S$ & 45 & 20.8 & 3.50 & 0.94 & 11.58 \\
\hline Caldas & Chardonnay & $2012 S$ & nd & 16.0 & 3.20 & 0.94 & 11.66 \\
\hline Três Corações & Syrah & $2012 \mathrm{~W}$ & 43 & 28.8 & 3.78 & 1.80 & 12.00 \\
\hline Andradas & Syrah & $2012 \mathrm{~W}$ & 54 & 17.6 & 4.09 & 3.80 & 12.00 \\
\hline Louveira & Syrah & $2012 \mathrm{~W}$ & 56 & 12.8 & 3.94 & 2.46 & 13.65 \\
\hline Baependi & Cab.sauvig & $2012 \mathrm{~W}$ & 70 & 14.4 & 3.82 & 2.06 & 14.60 \\
\hline SAAmparo & Syrah & $2012 \mathrm{~W}$ & 74 & 12.0 & 3.86 & 3.86 & 15.60 \\
\hline Três Corações & Syrah & $2012 \mathrm{~W}$ & 82 & 9.6 & 3.92 & 8.80 & 15.00 \\
\hline SAAmparo & Syrah & $2013 \mathrm{~W}$ & 41 & 28.8 & 3.64 & 2.46 & 14.00 \\
\hline Três Pontas & Syrah & $2013 \mathrm{~W}$ & 44 & 28.0 & 4.21 & 3.92 & 14.50 \\
\hline SSParaíso & Syrah & $2013 \mathrm{~W}$ & 50 & 20.8 & 3.92 & 2.46 & 14.00 \\
\hline Indaiatuba & Syrah & $2013 \mathrm{~W}$ & 58 & 24.8 & 3.79 & 1.86 & 13.00 \\
\hline São Bento & Syrah & $2013 \mathrm{~W}$ & 69 & 24.0 & 4.01 & 2.26 & 14.00 \\
\hline Vargem & Syrah & 2013W & 72 & 24.0 & 3.89 & 3.72 & 13.50 \\
\hline Vargem & Tempranillo & 2013W & nd & 15.5 & 4.05 & 4.19 & 16.00 \\
\hline Itobi & Syrah & $2014 \mathrm{~W}$ & 56 & 19.2 & 3.84 & 2.80 & 15.20 \\
\hline
\end{tabular}

${ }^{\star} \mathrm{S}=$ summer harvest; $\mathrm{W}=$ winter harvest $\uparrow$ nd $=$ MLF failure 
There is a clear correlation between the length of MLF, the potential inhibitors and the season. Alcohol strength plays an important role in reducing lactic bacterial activity. Summer wines with alcohol contents $<12 \%$ completed MLF in 45 days even at a $\mathrm{pH}<3.2$.

Lasik (2013) mentioned that an alcohol concentration $>8 \%$ reduces bacterial growth but not bacterial activity, while a free- $\mathrm{SO}_{2}$ concentration of $15 \mathrm{mg} \mathrm{L}^{-1}$ and a $\mathrm{pH}<3.5$ impair bacterial activity. Malolactic fermentation of Chardonnay wines from Caldas failed in the 2012 summer season; however, the wine compositions indicated lower free- $\mathrm{SO}_{2}$ and alcohol contents than Bordô wines from the same region and season. Red wines are fermented at higher temperatures, which may have contributed to bacterial growth and the success of MLF in Bordô wines. Comparing only Chardonnay wines, the high $\mathrm{pH}$ content of the Divinolândia sample counterweighted the high levels of free $\mathrm{SO}_{2}$, and malic acid was degraded within 45 days. In the Caldas sample, however, the free- $\mathrm{SO}_{2}$ content over $15 \mathrm{mg} \mathrm{L}^{-1}$, associated with low $\mathrm{pH}$ and low temperature, may have impaired lactic bacterial growth and activity.

The evaluation of lactic bacterial behavior in wine is difficult due to the complex composition of the wine. Compounds such as acetaldehyde and medium-chain fatty acids released by yeasts may impair lactic bacterial growth and reduce the bacteria's activity especially when associated with alcohol, a low $\mathrm{pH}$ and a high $\mathrm{SO}_{2}$ content (Carreté et al., 2002; Lasik, 2013). In culture media similar to wine, Wells \& Osborne (2012) observed that acetaldehyde concentrations over $5 \mathrm{mg} \mathrm{L}^{-1}$ and $10 \mathrm{mg} \mathrm{L}^{-1}$ of pyruvic acid inhibited Oenococcus oeni at $\mathrm{pH} 3.50$, while at $\mathrm{pH} 3.70$, the concentrations had to be increased to $10 \mathrm{mg} \mathrm{L}^{-1}$ for both compounds to have the same effect. Phenolic compounds may contribute to the activation or inhibition of bacterial growth depending on their structure, concentration or bacterial strain (García-Ruiz et al., 2008; Lasik, 2013). Pesticide residues are also mentioned as inhibitors of malic-acid degradation, and the presence of copper or dichlofluanid may impair MLF (Cabras et al., 1999; Carreté et al., 2002).

The presence of these potential inhibitors was searched in Chardonnay wines from Caldas and Andradas because of their similar compositions in alcohol, sugar and $\mathrm{pH}$ content. Piruvic acid was not detected in both samples, and the acetaldehyde concentration was higher in the Andradas samples ( $49.7 \mathrm{mg} \mathrm{L}^{-1}$ ) than the Caldas samples $\left(29 \mathrm{mg} \mathrm{L}^{-1}\right)$. These values are much higher than those mentioned by Wells \& Osborne (2012) as inhibitors of lactic bacterial activity, but not enough to inhibit MLF in wines from the Andradas sample. White wines have low phenolic compounds, since there is no maceration step. Derived compounds of hidroxicinamic acids and catechin were higher in the Andradas sample than the Caldas sample: $82.5 \mu \mathrm{g} \mathrm{mL}^{-1}$ and $60.64 \mu \mathrm{g} \mathrm{mL}^{-1}$ of chlorogenic acid and $15.86 \mu \mathrm{g} \mathrm{mL}^{-1}$ and $14.21 \mu \mathrm{g} \mathrm{mL}^{-1}$ of catechin, respectively. The phenolic concentration was much lower than the toxic limit of $500 \mathrm{mg} \mathrm{L}^{-1}$ mentioned by García-Ruiz et al. (2008). The lipid composition in both wines was below $0.10 \mathrm{~g} 00 \mathrm{~mL}^{-1}$, which impaired the evaluation of fatty acids. Concerning pesticide residues, only dithyocarbamate was detected at $0.499 \mathrm{mg} \mathrm{kg}^{-1}$ and $0.595 \mathrm{mg} \mathrm{kg}^{-1}$ in the Caldas and Andradas samples, respectively. Therefore, none of the potential inhibitors mentioned in the literature could explain the MLF failure in the Caldas samples.

However, alcoholic fermentation of the Caldas wine proceeded at $12{ }^{\circ} \mathrm{C}$, while the Andradas tank fermented at $14.5^{\circ} \mathrm{C}$. A low temperature associated with a low $\mathrm{pH}$ and a free- $\mathrm{SO}_{2}$ concentration above $15 \mathrm{mg} \mathrm{L}^{-1}$ may be responsible for the observed inhibition of MLF. Reguant et al. (2005) relate a minimum amount of $10^{5} \mathrm{FCU} \mathrm{mL}^{-1}$ Oenococcus oeni to the development of MLF. At the beginning of alcoholic fermentation, the lactic-bacteria population represents approximately $10^{2} \mathrm{FCU}$ $\mathrm{mL}^{-1}$; this value increases at the end of alcoholic fermentation. Authors observed MLF failure in trials with bacterial growth no higher than $2 \times 10^{3} \mathrm{FCU} \mathrm{mL}^{-1}$ at the end of alcoholic fermentation.

Grapevines harvested in the winter season accumulate more sugar, anthocyanins and total phenolic compounds (Favero et al., 2011). Yeast fermentation normally occurred at temperatures below $20^{\circ} \mathrm{C}$, and the alcohol content exceeded $14 \%$ in most of the samples. Under these conditions, apart from the high $\mathrm{pH}$ of the must (above 3.60), MLF is unpredictable (Table 1). A high free- $\mathrm{SO}_{2}$ concentration $\left(28.8 \mathrm{mg} \mathrm{L}^{-1}\right)$ did not inhibit MLF; however, wines from the same cultivar and vineyard displayed a positive correlation between the length of MLF and the alcohol content.

Ramos (2013) observed the effect of glucose (2 to $\left.10 \mathrm{~g} \mathrm{~L}^{-1}\right)$, ethanol (10\% to $15 \%)$ and $\mathrm{SO}_{2}\left(0-40 \mathrm{mg} \mathrm{L}^{-1}\right)$ in the inhibition of the following lactic bacteria in synthetic media: Leuconostoc spp., Lactobacillus spp., and Oenococcus oeni. There was no inhibitory effect of glucose or $\mathrm{SO}_{2}$; however, an alcohol content over $13 \%$ inhibited O.oeni, and above $14 \%$, all the strains were inhibited.

The Tempranillo wine sample displayed three inhibitor compounds at high concentrations: glucose $\left(4.19 \mathrm{~g} \mathrm{~L}^{-1}\right)$, alcohol (16\%) and acetaldehyde $\left(62.5 \mathrm{mg} \mathrm{L}^{-1}\right)$. While the alcohol content of Syrah wined from Itobi was high (15\%), the glucose and acetaldehyde contents were lower: $2.80 \mathrm{~g} \mathrm{~L}^{-1}$ and $15.8 \mathrm{mg} \mathrm{L}^{-1}$, respectively. The high glucose content $\left(8.80 \mathrm{~g} \mathrm{~L}^{-1}\right)$ in Syrah wines from Três Corações also delayed MLF (82 days) compared to those from Santo Antônio do Amparo (3.86 g L ${ }^{-1}$ and 74 days) and Itobi (2.80 $\mathrm{g} \mathrm{L}^{-1}$ and 56 days).

Wine is a complex medium for microbial growth, and composition, fermentation temperature, and microbial strain may contribute to either a delay in or an impairment of MLF.

Vineyards from different viticultural regions are a challenge for wineries; knowledge regarding both must composition and the temperature control of alcoholic fermentation should be taken into account to decrease the latent phase of lactic bacteria.

\section{Conclusions}

Native microflora adapts to the geographical origin.

Alcoholic-fermentation temperatures under $12^{\circ} \mathrm{C}$ decrease the metabolism of lactic bacteria and, when associated with a $\mathrm{pH}$ below 3.2 and free $\mathrm{SO}_{2}$ above $15 \mathrm{mg} \mathrm{L}^{-1}$, may impair their growth and activity after the lysis of yeast cells.

Winter wines may experience delays in MLF due to high alcohol and residual sugar contents. 


\section{Acknowledgements}

The authors are grateful to National Council for Scientific and Technological Development $(\mathrm{CNPq})$ and Minas Science funding agency (Fapemig) for financial support.

\section{References}

Amerine, M. A., \& Ough, C. S. (1980). Methods for analysis of musts and wines. New York: Willey.

Bokulich, N. A., Thorngate, J. H., Richardson, P. M., \& Mills, D. A. (2013). Microbial biogeography of wine grapes is conditioned by cultivar, vintage, and climate. Proceedings of the National Academy of Sciences of the United States of America, 111(1), 139-148. Retrieved from http://www.pnas.org/cgi/doi/10.1073/pnas.1317377110. PMid:24277822.

Cabras, P., Angioni, A., Garau, V. L., Pirisi, F. M., Farris, G. A., Madau, G., \& Emonti, G. (1999). Pesticides in fermentative processes of wine. Journal of Agricultural and Food Chemistry, 47(9), 3854-3857. PMid:10552734. http://dx.doi.org/10.1021/jf990005j.

Carreté, R., Vidal, M. T., Bordons, A., \& Constantí, M. (2002). Inhibitory effect of sulfur dioxide and other stress compounds in wine on the ATPase activity of Oenococcus oeni. FEMS Microbiology Letters, 211(2), 155-159. PMid:12076806. http://dx.doi.org/10.1016/S03781097(02)00687-0.

Edwards, C. G., \& Beelman, R. B. (1989). Inducing malolactic fermentation in wines. Biotechnology Advances, 7(3), 333-360. PMid:14542820. http://dx.doi.org/10.1016/0734-9750(89)90179-1.

Favero, A. C., Amorim, D. A., Mota, R. V., Soares, A. M., Souza, C. R., \& Regina, M. A. (2011). Double-pruning of 'Syrah' grapevines: a management strategy to harvest wine grapes during the winter in the Brazilian Southeast. Vitis, 50(4), 151-158.

García-Ruiz, A., Bartolomé, B., Martínez-Rodríguez, A. J., Pueyo, E., Martín-Álvarez, P. J., \& Moreno-Arribas, M. V. (2008). Potential of phenolic compounds for controlling lactic acid bactéria growth in wine. Food Control, 19(9), 835-841. http://dx.doi.org/10.1016/j. foodcont.2007.08.018.

Iorizzo, M., Testa, B., Lombardi, S. J., García-Ruíz, A., Muñoz-González, C., Bartolomé, B., \& Moreno-Arribas, M. V. (2016). Selection and technological potential of Lactobacillus plantarum bacteria suitable for wine malolactic fermentation and grape aroma release. Lebensmittel-Wissenschaft + Technologie, 73, 557-566. http://dx.doi. org/10.1016/j.lwt.2016.06.062.

Lasik, M. (2013). The application of malolactic fermentation process to create good-quality grape wine produced in cool-climate countries: a review. European Food Research and Technology, 237(6), 843-850. http://dx.doi.org/10.1007/s00217-013-2083-x.

Lerena, M. C., Rojo, M. C., Sari, S., Mercado, L. A., Krieger-Weber, S., \& Combina, M. (2016). Malolactic fermentation induced by Lactobacillus plantarum in Malbec wines from Argentina. South African Journal of Enology and Viticulture, 37(2), 115-123. http:// dx.doi.org/10.21548/37-2-827.
Lopez, I., Ruiz-Larrea, F., Cocolin, L., Orr, E., Phister, T., Marshall, M., Gheynst, J. V., \& Mills, D. A. (2003). Design and Evaluation of PCR Primers for Analysis of Bacterial Populations in Wine by Denaturing Gradient Gel Electrophoresis. Applied and Environmental Microbiology, 69(11), 6801-6807. PMid:14602643. http://dx.doi. org/10.1128/AEM.69.11.6801-6807.2003.

Mota, R. V., Silva, C. P. C., Favero, A. C., Purgatto, E., Shiga, T. M., \& Regina, M. A. (2010). Composição físico-químcia de uvas para vinho fino em ciclos de verão e inverno. Revista Brasileira de Fruticultura, 32(4), 1127-1137. http://dx.doi.org/10.1590/S010029452011005000001.

Pan, W., Jussier, D., Terrade, N., Yada, R. Y., \& Orduña, R. M. (2011). Kinetics of sugars, organic acids and acetaldehyde during simultaneous yeast-bacterial fermentations on white wine at different $\mathrm{pH}$ values. Food Research International, 44(3), 660-666. http://dx.doi.org/10.1016/j. foodres.2010.09.041.

Ramos, A. P. P. (2013). Influência da glucose, etanol e dióxido de enxofre no crescimento de bactérias do ácido lático. (Dissertação de mestrado). Universidade do Porto, Lisboa.

Ramos, C. L., Almeida, E. G., Pereira, G. V. M., Cardoso, P. G., Dias, E. S., \& Schwan, R. F. (2010). Determination of dynamic characteristics of microbiota in a fermented beverage produced by Brazilian Amerindians using culture-dependent and cultureindependent methods. International Journal of Food Microbiology, 140(2-3), 225-231. PMid:20413168. http://dx.doi.org/10.1016/j. ijfoodmicro.2010.03.029.

Regina, M. A., Mota, R. V., Souza, C. R., \& Favero, A. C. (2011). Viticulture for fine wines in Brazilian Southeast. Acta Horticulturae, (910), 113-120. http://dx.doi.org/10.17660/ActaHortic.2011.910.8.

Reguant, C., Carreté, R., Constantí, M., \& Bordons, A. (2005). Population dynamics of Oenococcus oeni strains in a new winery and the effect of $\mathrm{SO}_{2}$ and yeast strain. FEMS Microbiology Letters, 246(1), 111-117. PMid:15869969. http://dx.doi.org/10.1016/j. femsle.2005.03.045.

Ribéreau-Gayon, P., Glories, Y., Maujean, A., \& Dubourdieu, D. (2006). Handbook of Enology: the microbiology of wine and vinifications (2nd. ed., Vol. 1). West Sussex: John Wiley \& Sons. http://dx.doi. org/10.1002/0470010398.

Ruiz, P., Izquierdo, P. M., Seseña, S., \& Palop, M. L. (2010). Analysis of lactic acid bacteria populations during spontaneous malolactic fermentation of Tempranillo wines at five wineries during two consecutive vintages. Food Control, 21(1), 70-75. http://dx.doi. org/10.1016/j.foodcont.2009.04.002.

Suriano, S., Savino, M., Basile, T., Tarricone, L., \& Di Gennaro, D. (2015). Management of malolactic fermentation and influence on chemical composition of Aglianico red wines. Italian Journal of Food Science, 27, 310-319.

Wells, A., \& Osborne, J. P. (2012). Impact of acetaldehyde- and pyruvic acid-bound sulphur dioxide on wine lactic acid bacteria. Letters in Applied Microbiology, 54(3), 187-194. PMid:22150460. http://dx.doi. org/10.1111/j.1472-765X.2011.03193.x. 